\title{
Effect of the Geometric Parameters of the Rib-Channel and Porous Cathode on the Species Distribution in the Cathodes of Protonic Ceramic Fuel Cell Stack
}

\author{
Jiaqi Dai ${ }^{l}$, Delphine Uwaneza ${ }^{1}$, Aleksey Levtsev ${ }^{2}$, Zidong Yu ${ }^{l}$, Daifen Chen ${ }^{1, *}$ \\ ${ }^{1}$ School of Energy and Power Engineering, Jiangsu University of Science and Technology, Zhenjiang \\ 212100, China \\ ${ }^{2}$ National Research Ogarev Mordovia State University, Saransk 430005, Russia \\ *E-mail: dfchen01@163.com
}

Received: 30 September 2021 / Accepted: 29 October 2021 / Published: 6 December 2021

\begin{abstract}
Proton ceramic fuel cell (PCFC) has attracted more and more attentions because of its advantages in the intermediate temperature operation zone. In this paper, a typical 5-cells PCFC stack is established and can be used for three-dimensional calculated fluid dynamics (CFD) model. Then the effects of different configurations and geometric parameters on species distributing qualities within the cathode components are studied and discussed. The result shows that increasing the width of the rib channel and the thickness of the porous cathode can greatly enhancing the oxygen supplying and vapor removing capabilities, especially for those electrochemical reaction sites covered by the solid ribs. In order to improve the electrochemical reaction, a more practical cathode bipolar plate structure with PCFC should be further developed.
\end{abstract}

Keywords: Protonic ceramic fuel cell, Oxygen supplying and vapor removing capabilities, 3D calculated fluid dynamics, Structure and performance.

\section{$\underline{\text { FULL TEXT }}$}

(C) 2022 The Authors. Published by ESG (www.electrochemsci.org). This article is an open access article distributed under the terms and conditions of the Creative Commons Attribution license (http://creativecommons.org/licenses/by/4.0/). 